\title{
THE SOUTHEASTERN AREA OF THE BRAZILIAN CONTINENTAL MARGIN: ITS EVOLUTION DURING THE MIDDLE AND LATE CRETACEOUS AS INDICATED BY PALEOECOLOGICAL DATA
}

\author{
MARTA CLÁUDIA VIVIERS*, and RICARDO LATGÉ MILWARD DE AZEVEDO*
}

\begin{abstract}
Biostratigraphic and paleoecologic investigations of Albian through Maastrichtian sediments in the Santos and Campos basins made possible a preliminary reconstruction of the paleoenvironmental evolution of the southeastern Brazilian continental margin. Five major Albian-Maastrichtian depositional sequences have been recognized in the Campos and Santos basins, and their paleoenvironmental maps drawn. As result, it was possible to reconstruct the regional paleogeography of the area at the close of each sequence. This procedure allowed inferences concerning sea-level variations in the Southeastern Brazilian Continental Margin. The oldest marine fossil record in the Campos and Santos basins is found in thick Lower/Middle Albian carbonate layers. These sediments were deposited in a shallow neritic environment with hypersaline and oxygen-rich bottom waters. The Upper Albian sequence consists on marls and calcilutites deposited under deeper bathymetric conditions, mostly mid to deep neritic. Such relative sea-level rise is of global extent and contributed to lowering the salinity of the waters then covering the southeastern portion of the Brazilian continental margin. The Upper Albian carbonatic sequence is overlain by and Upper Cenomanian/Middle Turonian siliciclastic sequence with varied faunal content, interpreted as result of environmental fluctuations. This sequence records anoxic events and turbidite deposition interlay in normal marine deposits, environmental conditions ranging from deep neritic to upper bathyal. The depositional history of the two basins evolved separately from the Late Turonian through the Maastrichtian. The Santos Basin was subject to strong sedimentary influx that led to the development of marginal and shelf facies. In its turn, continuous sinkage of the Campos Basin allowed oceanic conditions to develop in the studied area during this time. The sedimentary record for this phase includes two sequences, separated by an intervening unconformity due to the lack of Campanian deposits.
\end{abstract}

\begin{abstract}
RESUMO A ÁREA SUDESTE DA MARGEM CONTINENTAL BRASILEIRA: SUA EVOLUCÃO DURANTE O CRETÁCEO MÉDIO E O SUPERIOR SEGUNDO INDICAM OS DADOS PALEOECOLÓGICOS. Investigações bioestratigráficas e paleoecológicas levadas a efeito em sedimentos albianos-maastrichtianos das bacias de Campos e Santos permitiram conhecer a evolução paleoambiental da porção sudeste da margem continental brasileira. Cinco seqüências deposicionais foram reconhecidas e seus distintos paleoambientes mapeados. Com isso, foi possível reconstruir a paleogeografia da região ao final de cada seqüência, propiciando inferências quanto ao comportamento do nível do mar na área sudeste da margem continental brasileira. Os primeiros fósseis marinhos das bacias de Campos e Santos ocorrem no espesso pacote carbonático Eo/Meso-Albiano e são próprios de ambientes de plataforma rasa submetidos a condiçốes de fundo oxigenados e hipersalinos. A seqüência seguinte, de idade neoalbiana, consiste em margas e calcilutitos depositados em ambientes mais profundos (Nerítico médio a profundo). Essa elevação relativa do nível do mar teve expressão global e contribuiu para diminuir a salinidade das águas do Atlântico Sul. Sobrejacente aos carbonatos albianos ocorre a seqüência siliciclástica cenomaniana/mesoturoniana, exibindo um conteúdo microfossilifero variado, que expressa com nitidez a instabilidade ambiental daquele período. Eventos ańxicos, episódios turbidíticos e períodos de condiçōes marinhas normais ficaram registrados nas camadas dessa unidade cronoestratigráfica. A história deposicional das duas bacias evoluiu de forma diferente a partir do Neoturoniano até o Maastrichtiano. Neste período, a Bacia de Santos foi submetida a um forte influxo sedimentar, o que propiciou o desenvolvimento e a expansão de fácies marginais e de plataforma. Enquanto isso, em Campos, desenvolviam-se condiçōes batimétricas cada vez mais profundas em razão, principalmente, do baixo aporte sedimentar que lhe era destinado.
\end{abstract}

INTRODUCTION The Campos and Santos basins lie along the East coast of Brazil. They represent two examples of passive marginal continental basins, whose sedimentary columns allow the reconstruction of the aspects of installation and evolution of the South Atlantic during the Mesozoic Era.

This work integrates the results obtained from biostratigraphic and paleoecologic studies done by various authors (Koutsoukos 1984, 1987, Viviers 1986, 1987, Viviers et al. 1986, Dias-Brito \& Azevedo 1986, Richter 1987). It presents a synthetized version of the evolution of the SE portion of the Brazilian continental margin. The paleogeographic interpretations are shown in the form of maps that indicate changes occurred in these two basins from the Albian to the Maastrichtian.

LOCATION OF THE AREA AND METHODOLOGY The investigated area is bounded by the parallels $21^{\circ}$ and $28^{\circ}$ South, and the meridians $40^{\circ}$ and $48^{\circ}$ West. Altogether 103 wells have been selected along a NE-SW belt, aproximately $200,000 \mathrm{~km}^{2}$ in area, that borders on the continental margin of the Campos and Santos basins (Fig. 1). Most of wells are concentrated in the Campos Basin, although the Santos Basin is considerably more extensive.

The biostratigraphic studies upon which this work is based involve planktonic foraminifera, calcareous nannoplankton, calcispherulids and palynomorphs recovered from well cuttings and cores. The paleoecological interpretations were mainly based on generic composition of the benthic foraminifera assemblages from each sample. The planktonic foraminifera, metazoans, radiolarians, palynomorphs, and calcareous algae furnished the secondary elements for this type of analysis. Once paleobathymetric curves were constructed for each well, it was possible to obtain paleoenvironmental maps which represent the most important stratigraphic horizons for the understanding of the evolution of the area. The integration of the zonations based upon marine and nonmarine organisms allowed more detailed investigation of the lateral variations of the biota in response to environmental changes.

Interpretation of electric logs and seismostratigraphic 
analyses aided in the study of the depositional history of the sedimentary sequences in the two basins.

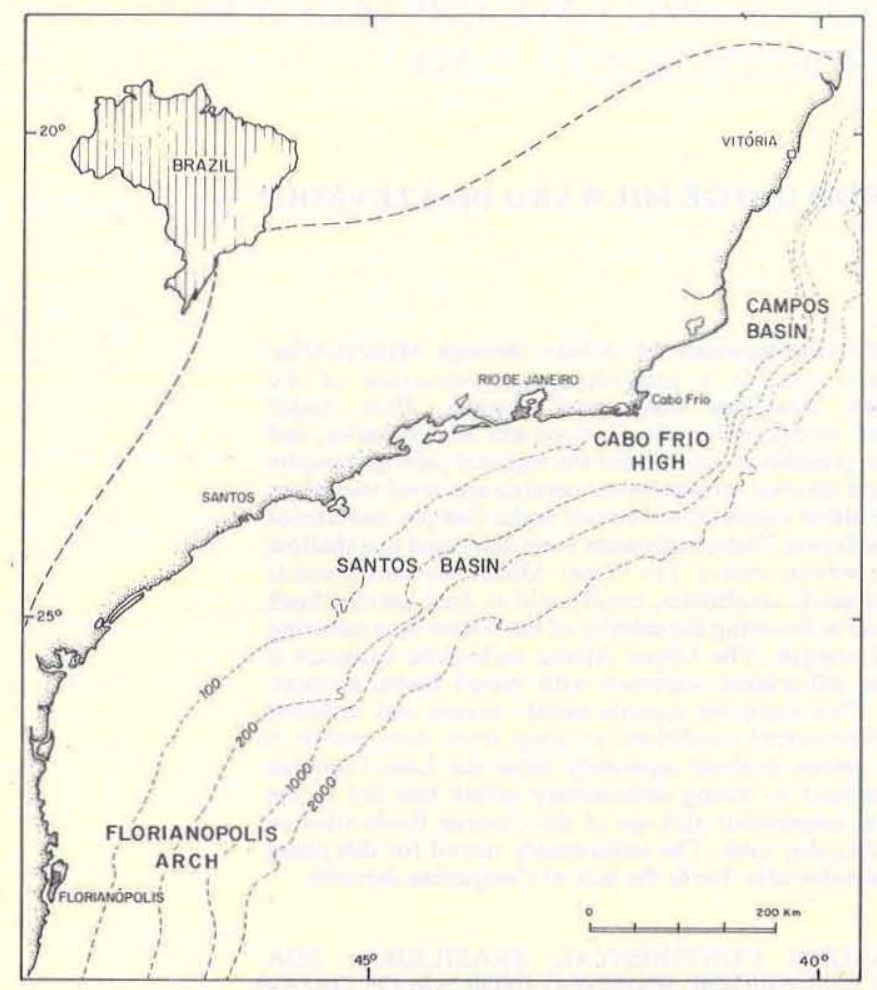

Figure 1 - Campos and Santos basins. Location map

\section{GEOLOGICAL FRAMEWORK AND STRATI-} GRAPHY The Santos and Campos basins are contiguous segments of the SE portion of the Brazilian continental margin. The Florianópolis Arch separates the Santos Basin to the south from Pelotas Basin. The limit of the Campos Basin to the north is the Vitória High, a geologic structure that separates it from the Espírito Santo Basin.

Four tectonic-sedimentary sequences are recorded in both basins in ascending order: nonmarine (rift-phase), evaporitic, pre-oceanic marine (chiefly carbonatic), and oceanic marine, where terrigeneous sediments predominate (Dias-Brito \& Azevedo op. cit., modified from Pontes \& Asmus 1976).

The lithostratigraphic units that make up the sedimentary column of the Campos Basin were formalized by Schaller (1973), whereas the corresponding units from Santos Basin were formalized by Ojeda \& Cesero (1973) and Ojeda \& Aranha (1980). The analyzed section includes the Macaé and Campos formations in the Campos Basin, and the Florianópolis, Guarujá, Itajaí, and Santos formations in the Santos Basin. The structural pattern and the distribution of reservoirs in these formations were controlled by salt tectonic processes, as demonstrated by Figueiredo \& Mohriak (1984) and Pereira et al. (1986).

Figure 2 presents a schematic chronostratigraphic picture where the Albo-Maastrichtian sequences from both basins are compared.

\section{BIOSTRATIGRAPHIC SYNTHESIS AND DISCUS- SION ABOUT THE HIATUSES The biostratigraphic} framework for the analysis of the SE portion of the Brazilian continental margin was based upon data from Azevedo et al. (1987a), Richter (op. cit), and Viviers (1986, 1987). The stratigraphic relationships among the several biozones utilized as well as their position in the International Chronologic Column are shown in figure 3. Most of the defined units are of the interval zone type, although some of them are still of informal status.
From a chronostratigraphic viewpoint, a uniform detailed study of the stages was not possible. The Albian, Turonian, Coniacian, and Maastrichtian were rather finely sliced, but not the Cenomanian, Santonian, and Campanian.

The obtained results show that distinctive hiatuses are present in section. These discontinuites were mainly indicated by absence of biozones, although in certain cases lithologic, seismic or paleoenvironmental evidence may be helpful in their detection. In this manner, for instance, the boundary between the Lower/Middle Albian sequence and the upper Albian sequence is shown to be of diastemic nature. Another hiatus, apparently of regional extent, is indicated by the regional scarcity of planktonic foraminifera and nannofossils of Early to Middle Cenomanian age. Azevedo et al. (op. cit.) discussed the hypothesis of the non-development of these organisms being due to ecologic constraints, but finally concluded that this section is actually absent in the Campos Basin. This gap was recognized in the wells of the Deep Sea Drilling Project (DSDP) in the South Atlantic, as shown by Magniez-Janin \& Müller (1987).

The Middle Cretaceous also includes a third discontinuity, which is restricted to the Campos Basin, and indicated by the scarcity of the Middle to Late Turonian sediments. It is only in the Santos Basin that species of planktonic foraminifera of this age are fairly common, such as Praeglobotruncana helvetica, P. gibba, Dicarinella hagni and D. algeriana.

The Upper Cretaceous also displays important hiatuses determined by the rare occurrence of Campanian deposits in the Campos Basin, and Late Maastrichtian sediments in the Santos Basin. This diachronism displayed by the great unconformities partially reflects the separate geologic history of the two basins after the Turonian.

Erosive events related to carving of canyons or to the uplift of specific areas have also given rise to discontinuites of varied magnitude and stratigraphic position in some parts of the two basins.

PALEOENVIRONMENTAL EVOLUTION The investigated sedimentary section overlies the barren evaporites of the Alagoas Stage (local stage of Early Cretaceous age) which were deposited during early phases of the South Atlantic evolution. Evidence of oceanic expansion during the Middle to Late Cretaceous is provided by carbonatic and siliciclastic units. This sedimentary section, accumulated during approximately $40 \mathrm{Ma}$, reveals marked paleoenvironmental alterations recognizable in micropaleontologic studies as well as in the form of variations in sedimentary facies and depositional systems. In general, they reflect the evolution of an oceanic margin of passive type, subject to the influence of tectonics and relative variations of the sea-level of either local or global extent. World-wide biologic and geochemical events were also recorded in the section.

The sedimentary column in the Campos and Santos basins is subdivided into five sequences: Lower/Middle Albian, Upper Albian, Cenomanian/Middle Turonian, Upper Turonian/Lower Campanian, and Upper Campanian/ Maastrichtian. Each of these megasequences is bounded by widespread unconformities, the corresponding hiatuses being estimated on basis of biozones absent in the section. The magnitude of the hiatus implied by any unconformity is not necessarily equal in both basins. This diachronism can be mainly ascribed to another geologic causes such as the rate of sedimentation and subsidence, or possibly to varied effects of erosion and/or tectonics in localized areas.

Continental, littoral, clastic, and carbonate continental shelf and continental slope environments were recognized in the studied section. The inferred paleogeographic evolution of the area, as well as its most distinctive erosive features are shown in paleobathymetric maps concerning several biostratigraphic horizons traceable in the two basins. 


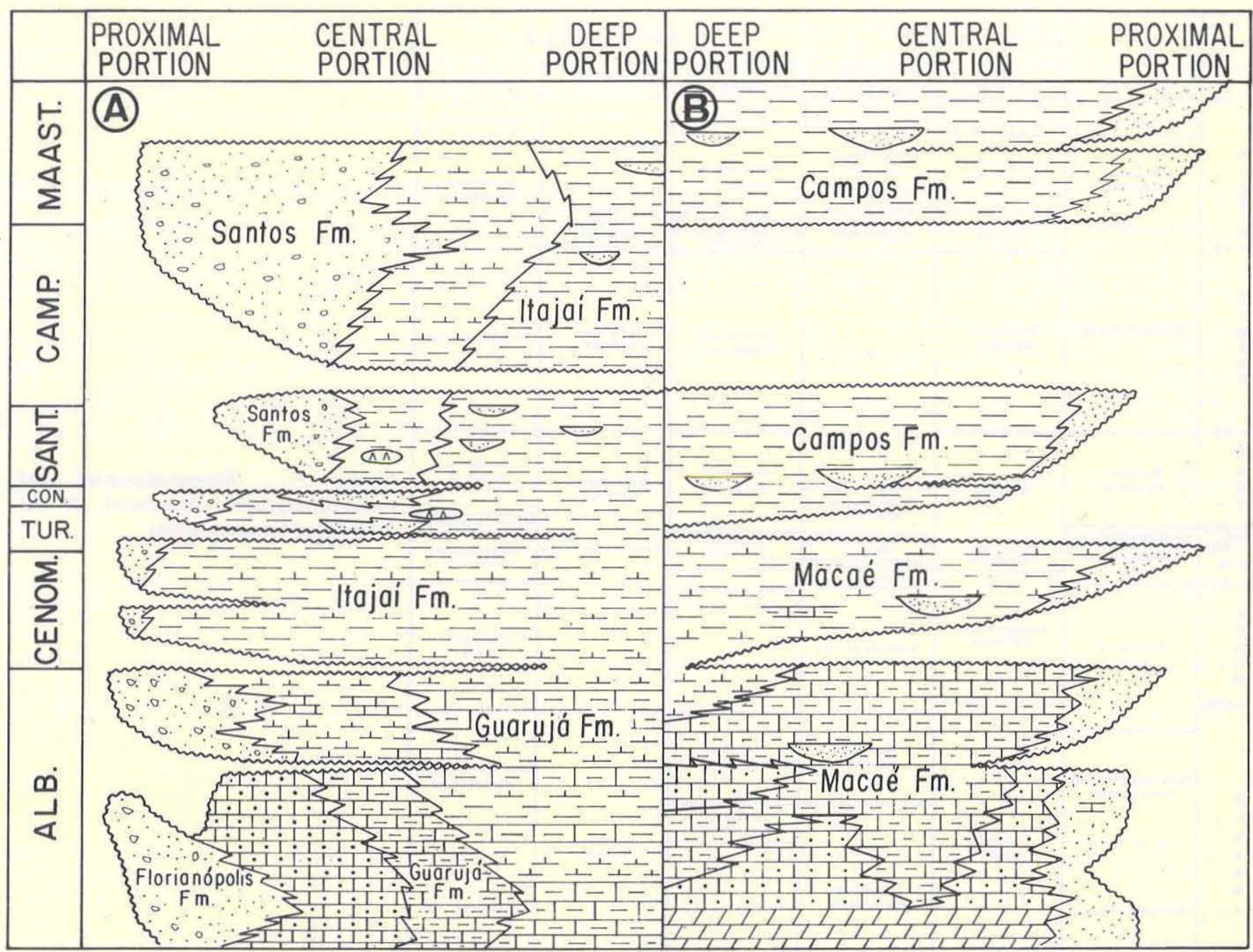

Figure 2 - Lithostratigraphic columns for the Santos $\mathbf{A}$ and Campos $\mathbf{B}$ basins

LOWER/MIDDLE ALBIAN Marine sedimentation in the Campos and Santos basins started by the late Alagoas time with the deposition of barren evaporitic layers. These were covered by a thick carbonatic section of Early/Middle Albian age which contains the oldest marine organisms known in these basins. Studies of the Campos area by Dias-Brito (1982). Dias Brito \& Azevedo (op. cit.), Azevedo et al. (1987b), Rodrigues \& Takaki (1987), and Spadini et al. (1988) demonstrate that these carbonates were formed under shallow marine oxygenated and hypersaline environmental conditions.

The section is represented by dolomites at the base, grading upward into oncolitic calcareous sandstones that make up most of the column. Towards the top, occasional calcilutites occur associated with the lower portions of the preterite carbonate ramp (Spadini et al. op. cit.). These rocks belong to the Macaé and Guaruja formations of the Campos and Santos basins, respectively.

Coastal, lagoonal, and deitaic environments were recognized in the western portion of the studied area (Florianópolis Formation in Santos Basin). Pereira et al. (op. cit.) recognized evidence of sea-level lowerings such as paleosoils, erosive chutes, and reddish clastics on top of this interval.

In general, micropaleontologic associations recovered from this unit are poor and very little diversified. The benthic elements are predominant and include foraminifera, ostracods, micromolluscs, enchinoids, and algae (charophytes). The planktonic microfauna occurs rather infrequently concentrated on top of the section.

The paleobathymetric map for the Early/Middle Albian (Fig. 4) shows a monotonous, regular distribution of neritc environment, proper to a low gradient carbonate ramp with inferred water depth of less than $30 \mathrm{~m}$. The deeper environmental conditions were recognized in the northeastern most part of the studied area, where the sea bottom was probably steeper

UPPER ALBIAN This stratigraphic interval is relatively uniform in thickness and well represented in both basins. Calcilutites, which grade into rhythmic calcilutites and marls, make up most of the section. Conglomerates and sandstones found in the proximal portions are interpreted to represent coastal fan systems developed laterally to the carbonatic platform (Pereira et al. op. cit., Spadini et al. op cit.). The upper Guarujá and Florianópolis Formations in the Santos Basin and the carbonates of the "Upper Macaé" in the Campos Basin are lithostratigraphic units representative of this interval.

The Upper Albian fauna, richer and more diverse than that of the underlying unit, is dominated by planktonic elements. However, low diversity and frequency of the benthic microfauna indicate that constraints to the full development of sea-bottom biota still persited during this time, as demonstrated by Dias-Brito (op. cit.).

Two important biologic events are recorded in the section. The first concerns the sudden disappearance of Favusella 


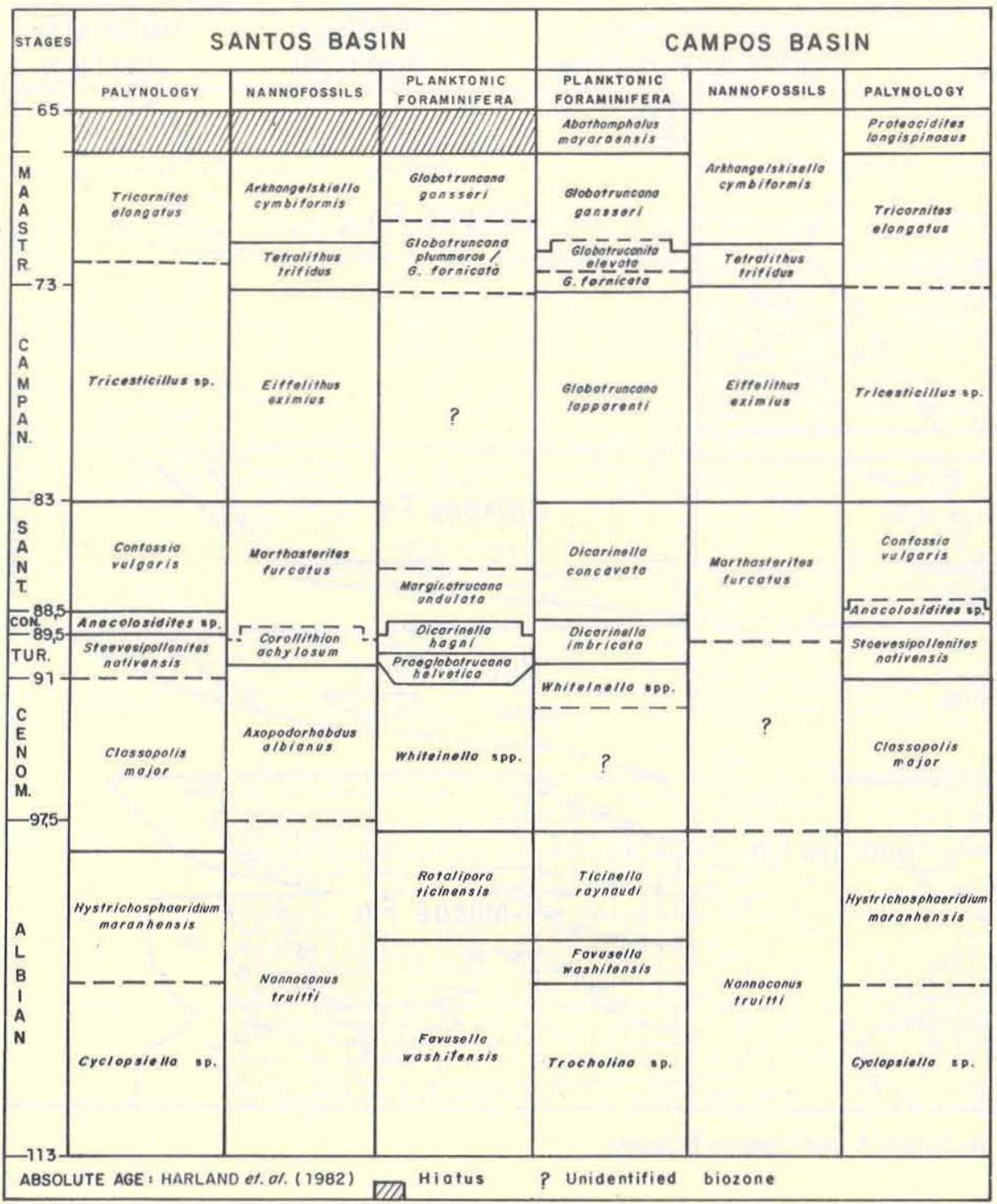

Figure 3 - Bioestratigraphic and cronoestratigraphic framework for the Santos and Campos basins

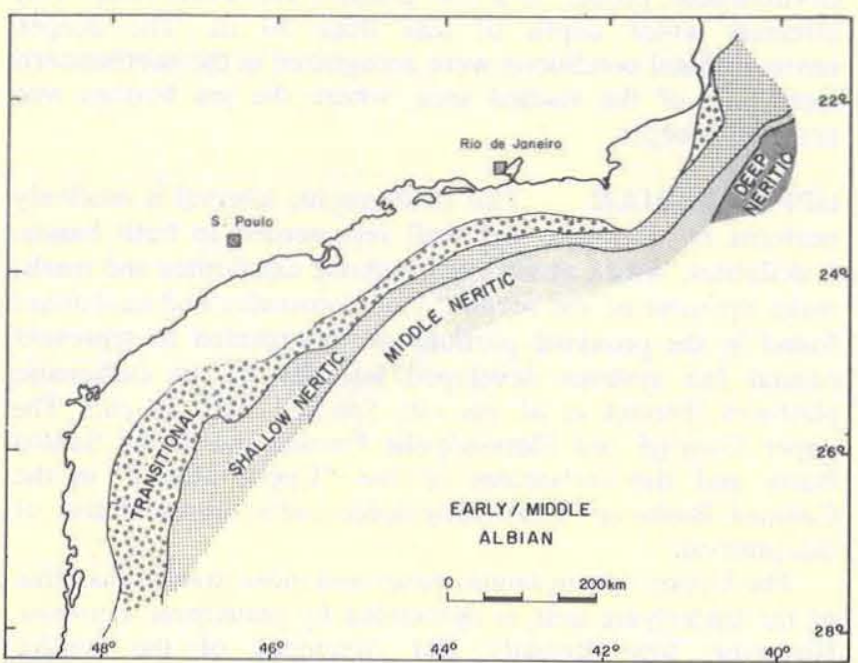

Figure 4-Paleobathymetric map for the Early-Middle Albian. Datum: top of the Cyclopsiella sp. Zone washitensis within the sequence, which may be ascribed to increased terrigenous influx into the basin as well as to a sea-level rise of great magnitude. The second biologic event is represented by the appearance of keeled planktonic foraminifera, and points out of the open communication of the South Atlantic and Tethys seas by the latest Albian, as discussed in Magniez-Jannin \& Müller (op. cit.) and Dias-Brito (1987).

Comparison of the paleobathymetric map for the Upper Albian (Fig. 5) with map for the Lower/Middle Albian makes apparent a westerly shift of the isobathymetric curves. This is interpreted as evidence of relative sea-level rise during the Late Albian, when the region was submitted to relatively deeper neritic conditions (dominantly deep neritic to upper bathyal). Shallower environments occurred in the SE portion of the studied area, where terrigeheous supply was more effective. Although the sediments in this section are considered to have totally covered both basins, some areas were later affected by tectonism or canyon excavation, in which these deposits were totally or partially eroded.

CENOMANIAN/MIDDLE TURONIAN This chronostratigraphic unit is represented in the Campos and Santos 


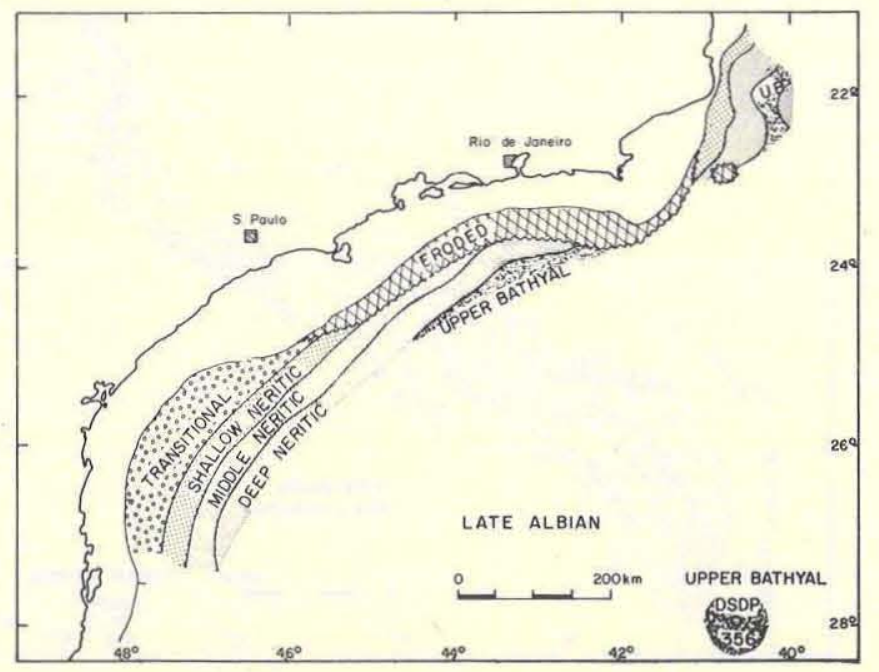

Figure 5-Paleobathymetric map for the Late Albian. Datum: top of the Hystrichosphaeridium maranhensis Zone

basins by a sequence of marls and shales, with minor turbiditic sands and coarse clastics. These sediments belong to the Macaé, Itajaí, and Santos Formations.

The chronostratigraphic range of this unit is still rather controversial. Azevedo et al. (op. cit.) suggest that the Lower/Middle Cenomanian is absent in the Campos Basin due to the lack of proven index fossils for this time. In its turn, the top of the sequence is clearly diachronous, with the of Praeglobotruncana helvetica zone (indicative of Middle Turonian) occuring only in the Santos Basin.

The Cenomanian/Middle Turonian fauna is significantly different from that occuring in the Albian carbonates. The distribution of foraminifera along the section is considerably varied, and differences are also observed when associations recovered from the two basins are compared. The benthic fauna is predominant in the Campos Basin, where textulariids are the commonest foraminifera. There are horizons in which biotic diversity is high and frequency is low, whereas in some other levels both are low. There are still cases of high frequency and low diversity of benthic elements, such as the buliminid associations indicative of euxinic environment (Azevedo et al.op. cit.).

In the Santos Basin, in its turn, a more abundant and diversified association of planktonic foraminifera was recovered, which includes many keeled species (Viviers 1986, 1987). The benthic microfossils are less frequent and generally restricted to a few horizons where nodosariids, primitive textulariids or buliminids predominate. These associations are similar to those found by Hart \& Bigg (1981), Bernhard (1986), and Nyong \& Ramanathan (1985) in less oxygenated environments, and occur within beds of relatively high organic matter content (Arai 1987). These sediments are genetically related to the "second global anoxic event" of Arthur \& Schlanger (1979), identified in several points of the South Atlantic (Herbin et. al. 1987).

According to current paleoecologic interpretations, the Cenomanian-Middle Turonian marls and shales were deposited under water depth of $100-300 \mathrm{~m}$ within a basin of relatively gentle gradient. Comparison of the map for this unit (Fig. 6) with that for the Late Albian sequence makes evident a westerly shift of the bathyal environments. Shallower paleobathymetric conditions are recognized in the southwestern portion of the Santos Basin as result of predominance of sedimentary accumulation processes over basin subsidence. This gave rise to local progradational conditions during a period of relative sea-level rise of global extent (Haq et al. 1987). The strike section in figure 7 shows the uniform charactec of the Albian-Middle Turonian sequence, only modified at the southern end of the Santos Basin due to the locally significant sedimentary supply.

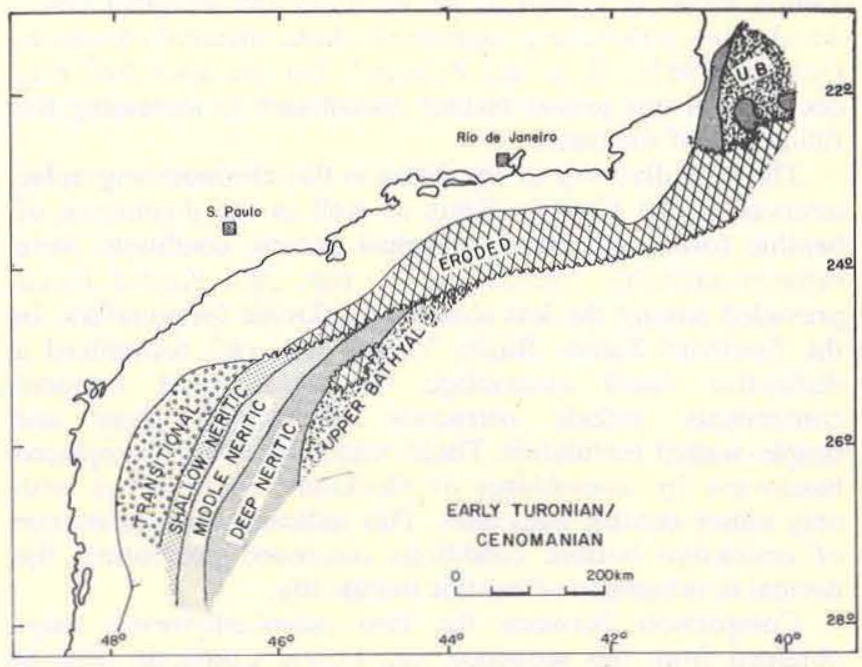

Figure 6 - Paleobathymetric map for the Cenomanian-Early Turonian. Datum: top of the Classopollis major Zone

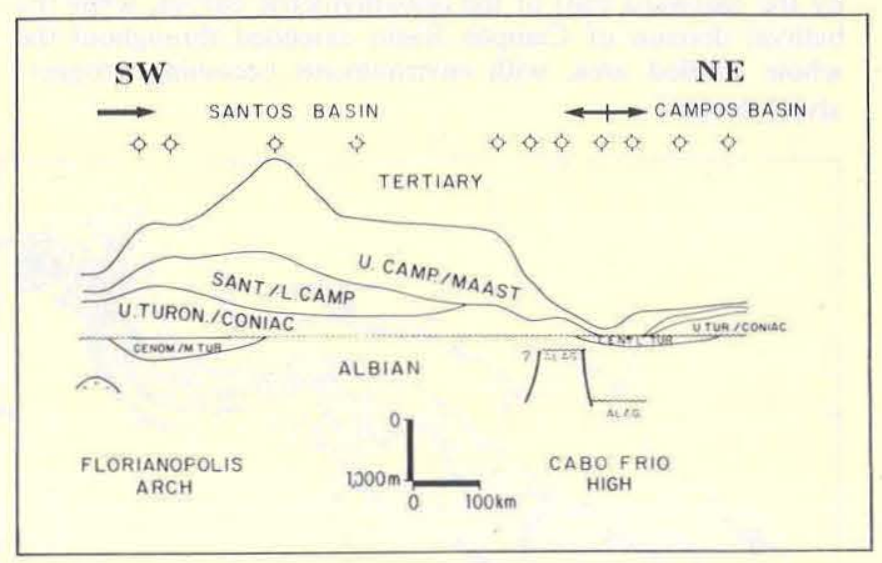

Figure 7 - Schematic strike sections showing variations in thickness in Cenomanian through maastrichtian sediments, in the Santos and Campos basins. Datum: top of Classopollis major Zone

The section of Cenomanian/Middle Turonian age was not recorded within a wide E-W band extending from the north of the Santos Basin to the South of the Campos Basin. This hiatus is interpreted to be of erosive origin and latest Turonian age. It results from intense regional tectonic adjustments, which enhanced the Cabo Frio structural high and favoured the intrusion of the alkaline rocks (Macedo 1987).

UPPER TURONIAN/LOWER CAMPANIAN The two sedimentary basins evolved separately since the Late Turonian in that large amounts of sediments were deposited in the Santos Basin, as opposed to less impressive sedimentary accumulation in the Campos Basin. This tendency is clearly recognizable in the Upper Turonian/Lower Campanian section, which in the Santos Basin is repesented by a thick, dominantly coarse siliciclastic sequence. In the Campos Basin this unit is represented by shales with minor marls and turbiditic sandstones. As concerns lithostratigraphy, these 
rocks belong to the Santos and Itajaí formations of the Santos Basin, and in the Campos Formation of the Campos Basin.

The strike section of figure 7 shows the variation within this sedimentary sequence. The high sedimentation rate in the Santos Basin is related to the uplift of the marginal areas, which have yielded large masses of clastic material (Asmus \& Guazelli 1981). It is also believed that sea-level lowering occurred in this period further contributed to increasing the filling rate of the basin.

The high diversity of the fauna in this chronostratigraphic interval of the Campos Basin as well as the dominance of benthic forms indicative of normal oceanic conditions were demonstrated by Azevedo et al. (op. cit.). Keeled forms prevailed among the less abundat planktonic foraminifera. In the Southern Santos Basin, Viviers (op. cit.) recognized a distinctive fossil assemblage, in which most frequent constituents include ostracods, charophyte algae and simple-walled textularids. These coastal biofacies are replaced basinward by assemblages of planktonic foraminifera with only minor benthic associates. This indicates that persistence of restrictive bottom conditions continued preventing, the normal development of benthic marine life.

Comparison between the two paleobathymetric maps obtained from this sequence, i.e., Lower Coniacian (Fig. 8) and Upper Coniacian/Santonian (Fig. 9), makes evident the different environmental domains to which the Santos and Campos basins were subject. Progressively shallower neritic conditions were developed in the Campos Basin, as indicated by the eastward shift of the isobathymetric curves, while the bathyal domain of Campos Basin extended throughout the whole studied area, with environments becoming progressively deeper.

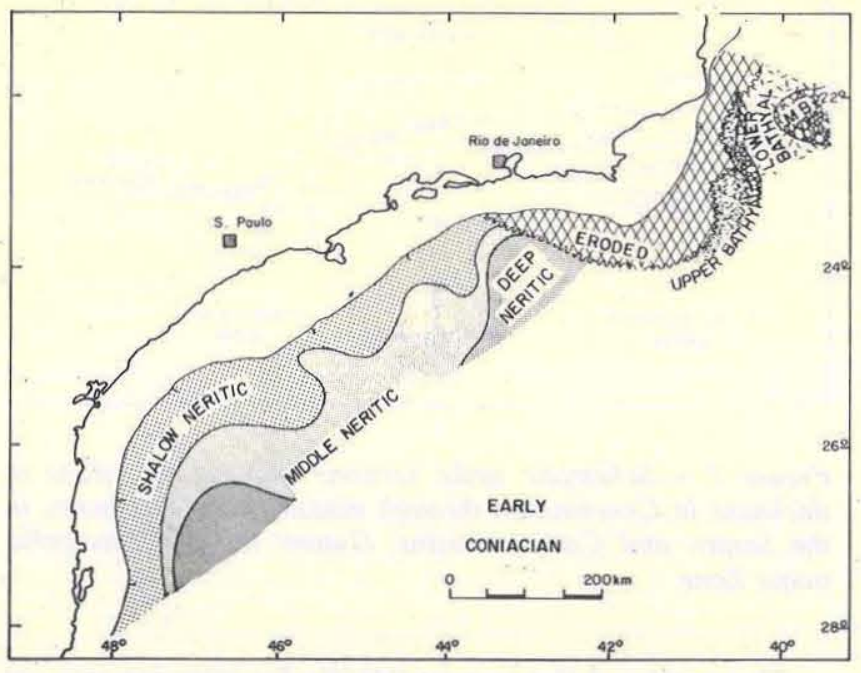

Figure 8 - Paleobathymetric map for the Early Coniacian. Datum: top of the Anacolosidites sp. Zone

UPPER CAMPANIAN/MAASTRICHTIAN This interval displays different chronostratigraphic ranges in each basin. Lithologically it is made up of siliciclasctics, dominantly coarse in the Santos Basin (Santos Formation), whereas shales prevail in the Campos Basin (Campos Formation). The Upper Maastrichtian is seldom recognized in the Santos Basin, whereas the Upper Campanian is uncommon in the Campos area.

The quite different faunal composition revealed by this unit in both basins reflects the distinct environmental conditions to which the Campos and Santos basins were subject. Agglutinate benthic Foraminifera characteristic of bathyal environmental (Azevedo et al. op. cit.) prevail in the former, whereas faunal and floral elements indicative of

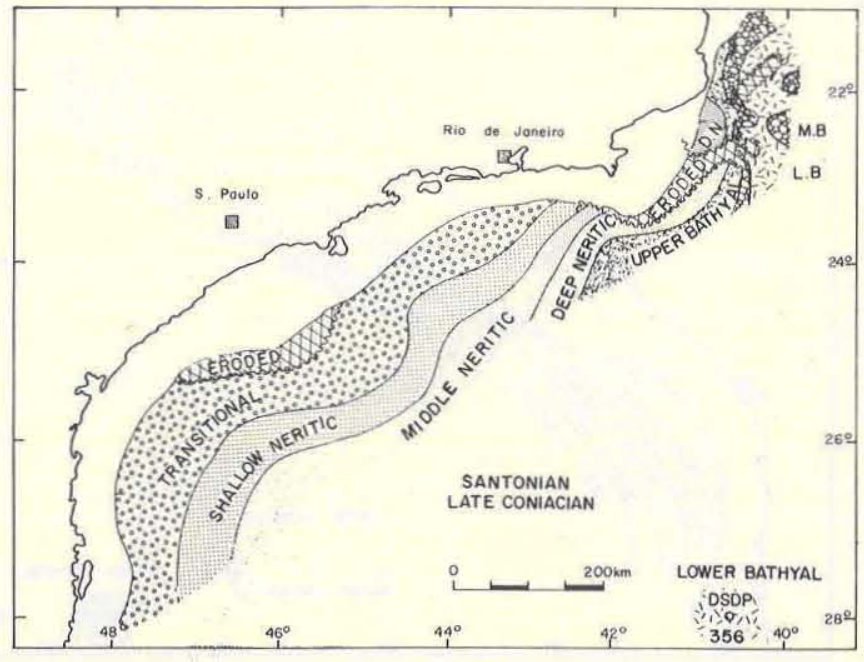

Figure 9 - Paleobathymetric map for the Late ConiacianSantonian. Datum: top of the Confossia vulgaris Zone

proximal environment were abundant in the latter. Transgressive and regressive pulses may be recognized in the Santos Basin based on compositional variation of fossil assemblages through the section (Viviers op. cit.).

The paleobathymetric map of the studied area (Fig. 10) illustrates the environmental conditions of the two basins during the Maastrichtian. Comparison of this map with the previous one makes evident the expansion of the bathyal domains in the Campos area, as well as the increasing steepness of the marine bottom in the Santos area accompanying the westward shift of the neritic environments. Considerable supply of terrigenous sediments during this period caused continental to transitional facies to develop in the proximal portion of the basin.

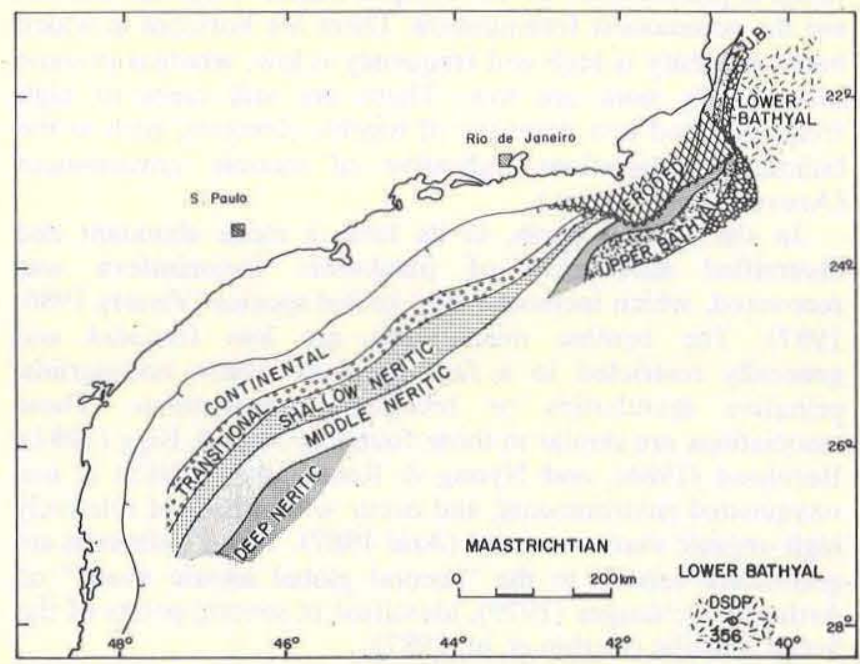

Figure 10 - Paleobathymetric map for the Maastrichtian. Datum: top of the Globotruncana gansseri and Arkhangelskiella cymbiformis zones

GENERAL CONSIDERATIONS AND CONCLUSIONS Biostratigraphic paleoenvironmental, seismic, and sedimentological data have been integrated in order to define the evolution of the SE portion of the Brazilian continental margin. The main considerations and conclusions of this study are the following: 
- The Cretaceous section of Campos Basin was deposited during a phase of relative sea-level rise with only eventual drops of short duration (Fig. 11). Such tendency fits well the evolutive pattern of the Brazilian marginal basins indicated by Beurlen (1982) and the predictive curve of global sea-level behavior (Haq et al. 1987).

- The evolutive pattern recognized for the Santos Basin is similar to that of the Campos region until the Early Turonian. However, from Late Turonian the sedimentary supply in the Santos Basin surpassed or compensated the subsidence rate. So that, a dominantly regressive local tendency characterizes the Upper Cretacious section of the Santos Basin. Positive features in the North and South margins probably contributed to originating a larger embayment, thus facilitating the accumulation of incoming sediments. Also, the tectonics in marginal areas, associated with alkaline igneous intrusions, contributed to significantly increasing the accumulation of sediments in the Santos Basin (Fig. 12).

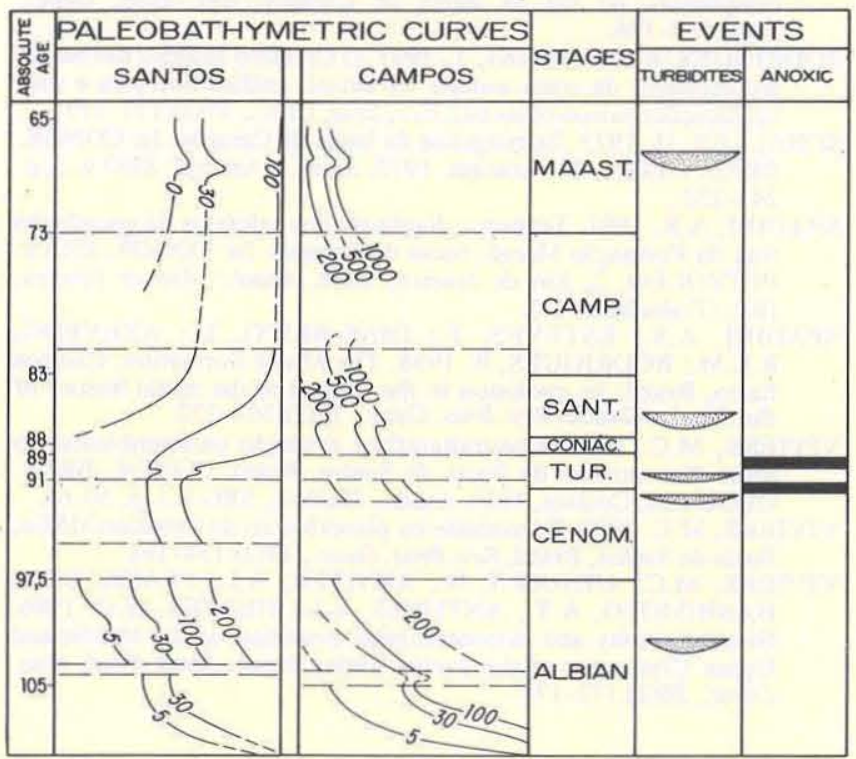

Figure 11 - Generalized paleobathymetric curves for the Santos and Campos basins and their relationships with anoxic events and turbidites

- Relative sea-level rises of third order are indicated in the Late Albian, Late Cenomanian/Early Turonian, Santonian, Late Campanian, and Maastrichtian. Those events had different effects in the two basins due to distinct regional physiography of the marine bottom. Relative eustatic lowerings were indicated late in the Early/Middle Albian and during the Late Albian, Late Turonian, Coniacian, Campanian, and Maastrichtian. The presence of turbiditic bodies and coastal sandstones tongues in these sections is evidence of drops of the regional base level (Fig. 11).

- During the Cenomanian/Late Turonian both basins were episodically subject to anoxic conditions, allowing the
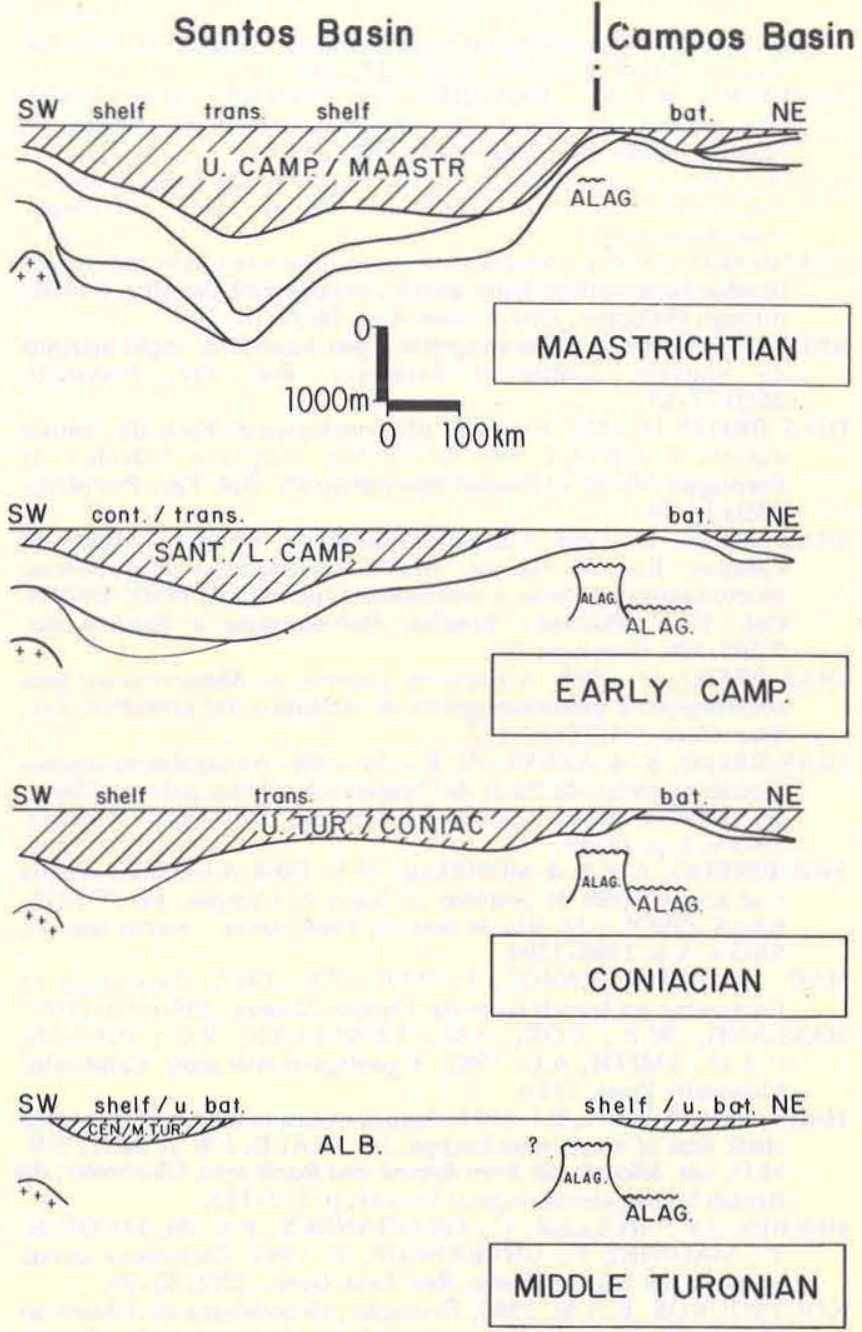

Figure 12 - Schematic strike section showing the different sedimentary evolution of the Santos and Campos basins since the Turonian

accumulation of sediments with high organic matter content. This episode is related to the so called "second global anoxic event" (Arthur \& Schlanger 1979) whose origin is not yet sufficiently understood (Fig. 11).

- The variation in extent of the hiatus around the area contiguous to the two basins (Figs. 4 to 6 ), as indicated by the successive paleobathymetric maps, suggests that the Cabo Frio High underwent strong uplift during the latest Turonian. In the maps obtained for subsequent stages (Fig. 8 through $10)$, the isobathymetric curves tend to contour this feature, demonstrating that it was part of the physiography of the regional Late Cretaceous marine bottom.

Acknowledgments The authors thank the management of Petrobrás, for permission to publish this paper. We are most grateful to José Henrique G. Melo, for significant improvement of the manuscript.

\section{REFERÊNCIAS BIBLIOGRÁFICAS}

ARAI, M. 1988. Geochemical reconnaisance of the Mid-Cretaceous anoxic events in Santos Basin, Brazil, Rev.Bras. Geoc., 18(2):273-282.

ARTHUR, M.A. \& SCHLANGER, S.O. 1979. Cretaceous oceanic anoxic events as causal factors in development of reef reservoir giant oil fields. AAPG Bull, 63(6):870-885.

ASMUS, H. \& GUAZELLI, W. 1981. Descrição sumária das estruturas da margem continental brasileira e das áreas oceânicas continentais adjacentes - hipótese sobre o tecnonismo causador e implicações para prognósticos do potencial de recursos minerais. In: PETROBRÁS. Estruturas e tectonismo da margem continental brasileira, e suas implicaçōes nos processos sedimentares e na avaliação do potencial de recursos minerais. Rio de Janeiro. Cenpes/Dintep. p. 187-269. (Série Projeto Remac 9).

AZEVEDO, R.L.M.; GOMIDE, J.; VIVIERS, M.C.; HASHIMOTO, 
A.T. 1987a. Bioestratigrafia do Cretáceo marinho da Bacia de Campos, Brasil. Rev. Bras. Geoc., 17(2):147-153.

AZEVEDO, R.L.M.; GOMIDE, J.; VIVIERS, M.C, $1987 \mathrm{~b}$ Geo-história da Bacia de Campos, Brasil, do Albiano a Maastrichtiano. Rev. Bras. Geol., 17(2):139-146.

BACOCCOLI, G. \& ARANHA, L.G. de 1981. Evolução estrutural do Fanerozóico do Brasil Meridional. Rio de Janeiro Petrobrás. (Internal report).

BERNHARD, J, 1986. Characteristic assemblages and morphologies of benthic foraminifera from anoxic, organic rich deposits: Jurassic through Holocene. Jour. Foram. Res., 16(3):207-215.

BEURLEN, G. 1982. Bioestratigrafia e geo-história da seção marinha da margem continental brasileira. Bol. Téc. Petrobrás, 25(2):77-83.

DIAS -BRITO, D. 1982. Evoluçāo paleoecológica da Bacia de Campos durante a deposição dos calcilutitos, margas e folhelhos da Formaçāo Macaé (Albiano/Cenomaniano?). Bol. Téc. Petrobrás, 25(2):11-24.

DIAS-BRITO, D, 1985. Calcisphaerulidae do Albiano da Bacia de Campos, Rio de Janeiro, Brasil: investigaçōes taxonômicas, biocronoestratigráficas e paleoambientais. Brasil, MME-DNPM. Col. Trab. Paleont., Brasília. Paleontologia e Estratigrafia, 2:295-306. (Geologia 27).

DIAS-BRITO, D, 1987. A Bacia de Campos no Mesocretáceo: uma contribuiçảo à paleoceanografia do Atlântico Sul primitivo. Rev. Bras, Geoc., 17(2):162-167.

DIAS-BRITO, D. \& AZEVEDO, R.L.M. 1986. As seqüências deposicionais marinhas da Bacia de Campos sob a óptica paleoecológica. In: CONGR. BRAS. GEOL., 34, Goiânia, 1986. Anais... Goiânia, SBG v. 1, p. 38-49.

FIGUEIREDO, A.M.F.\& MOHRIAK, W.U. 1984. A tectônica salífera e as acumulaçöes de petróleo na Bacia de Campos. In: CONGR. BRAS. GEOL., 33, Rio de Janeiro, 1984. Anais... Rio de Janeiro, SBG v. 3, p. 1380-1394.

HAQ, B.U.; HARDENBOL, J.; VAIL, P.R. 1987. Chronology of fluctuating sea leavels since the Triassic. Science, 235:1156-1166.

HARLAND, W.B., COX, A.V.; LEWELLYN, P.G.; PIKTON, C.A.G.; SMITH, A.G. 1982. A geological time scale. Cambridge University Press, 131 p.

HART, M.B \& BIGG, P J, 1981. Anoxic events in the Late Cretaceous chalk seas of north-west Europe. In: NEALE, J.W. \& BRASIER, M.D. eds. Microfossils from Recent and fossils seas. Chichester, the British Micropaleontological Society. p. 177-185.

HERBIN, J.P.; MUULLER, C.; GRACIANSKY, P.C. de; JACQUIN, T. MAGNIEZ F.; UNTERNEHR, P. 1987. Cretaceous anoxic events in the South Atlantic. Rev. Bras. Geoc.. 17(2):92-99.

KOUTSOUKOS, E.A.M. 1984. Evolução paleocológica do Albiano ao Maastrichtiano na área noroeste da Bacia de Campos, Brasil, com base em foraminíferos. In: CONGR. BRAS. GEOL., 33, Rio de Janeiro, 1984. Anais... Rio de Janeiro, SBG. v, 2, p. 685-698.

KOUTSOUKOS, E.A.M. 1987. A área noroeste da Bacia de Campos, Brasil, do Mesocretáceo ao Neocretáceo: evoluçăo paleoambiental e paleogeográfica através de estudos de foraminíferos. Rev, Bras. Geoc., 17(2):168-172.

MACEDO, J.M. 1987. Evolução estrutural da Bacia de Santos e áreas continetais adjacentes. Ouro Preto. Univ. Fed. Ouro Preto. (MS thesis).
MAGNIEZ-JANNIN, F. \& MÜLLER, C. 1987. Cretaceous stratigraphy and paleoenvironmental data from the South Atlantic (foraminifers and nannoplankton). Rev. Bras. Geoc., 17(2): $100-105$.

NYONG, E.E. \& RAMANATHAN, R.M. 1985. A record of oxygen deficient paleoenvironments in the Cretaceous of the Calabar Flank, SE Nigeria. Jour. African Earth Sciences, 3(4):455-460.

OJEDA, H.A. 1980. Bacia de Santos, integração geológica. Rio de Janeiro, Petrobrás. (Internal report)

OJEDA, H.A., \& CÉSERO, P. 1973. Bacias de Santos e Pelotas, geologia e perspectivas petroliferas. Rio de Janeiro, Petrobrás. (Internal report).

OJEDA, H.A \& ARANHA, L.G.F. 1980, Bacia de Santos, integraçäo geologica regional. Rio de Janeiro, Petrobrás, (Internal report).

PEREIRA, M.J.; BARBOSA, C.M.; AGRA. J.; GOMES; J.B.; ARANHA, L.G.F.; SAITO, M.; CARVALHO, M.D. de; STAMATO, M. 1986. Estratigrafia da Bacia de Santos: análise das seqüências, sistemas deposicionais e revisão litoestratigráfica. In: CONGR. BRAS. GEOL., 33, Rio de Janeiro, 1984. Anais... Rio de Janeiro, SBG v. 1, p. 65-79.

PONTES, F.C. \& ASMUS, H.E. 1976. The Brazilian marginal basins: current state of knowledge. Anais Acad. bras. Ciênc., 48(supl.):215-239.

RICHTER A.J. 1987. Subafloramentos das discordâncias turoniana e campaniana no sul da Bacia de Campos. Rev. Bras. Geoc., 17(2):173-176.

RODRIGUES, R. \& TAKAKI, T. 1987. O Cretáceo Inferior nas bacias sedimentares da costa sudeste do Brasil: análise isotópica e suas implicaçōes paleoambientais. Rev. Bras. Geoc., 17(2):177-179.

SCHALLER, H. 1973. Estratigrafia da bacia de Campos. In: CONGR. BRAS. GEOL., 27, Aracaju, 1973. Anais... Aracajú, SBG v. 3, p. 247-258.

SPADINI, A.R. 1982. Textura e diagênese dos calcários de granulação fina da Formaçāo Macaé, Bacia de Campos. In: CONGR. BRAS. PETRÓLEO, 2, Rio de Janeiro, 1982. Anais... Rio de Janeiro, IBP. (Trabalho ne 18),

SPADINI, A.S.; ESTEVES, F.; DIAS-BRITO, D.; AZEVEDO, R.L.M. RODRIGUES, R. 1988. The Macaé Formation, Campos Basin, Brazil: its evolution in the context of the initial history of the South Atlantic. Rev. Bras. Geoc., 18(2):261-272

VIVIERS, M.C. 1986. Bioestratigrafia e evoluçâo paleoambiental do Meso-Neocretáceo da Bacia de Santos, Brasil. CONGR. BRAS. GEOL., 34, Goiânia, 1986. Anais... Goiânia, SBG v.1, p. 50-64.

VIVIERS, M.C. 1987. Foraminíferos planctônicos do Cretáceo Médio, Bacia de Santos, Brasil, Rev. Bras, Geoc., 17(2):154-161.

VIVIERS, M.C.; UESUGUI, N.; RICHTER, A.J.; PRAÇA, U.M.; HASHIMOTO, A.T., ANTUNES, R.L.; HERTER, G.G. 1986 Biostratigraphy and paleoecological evolution of the Middle and Upper Cretaceous of the Santos Basin, Brasil. Anais Acad. bras. Ciênc., 58(1):172-173.
MANUSCRITO 517

Recebido em 08 de janeiro de 1988 Revisão aceita em 09 de maio de 1988 